\title{
GARIBALDI AND THE FIRST PEACE CONGRESS IN GENEVA IN I867
}

As is well known the advocacy of pacifism is almost as old as war itself although organized attempts to outlaw war date only from the middle nineteenth century, and among these the Congres de la Paix of I 867 played a unique rôle. First it foreshadowed the permanency of Geneva as its logical seat, at least in the all-important area of Europe, and secondly, it dared attack the immediate conditions which predisposed nations to eventual belligerency. In a way, the United Nations could be considered as a realization of some of the ideals which inspired the daring initiative taken by the 1867 Congress, even though it was attacked as being anarchistic and revolutionary at that time. In fact the ' 67 Congress ended in a furore over this issue and although it continued its work until World War I it was practically obliged to confine its efforts along the less explosive lines of arbitration and international jurisdiction.

In 1820 already Geneva seemed predestined for such a rôle, when Count Jean Jacques de Sellon, Cavour's Genevese uncle, founded the Sociéte de la Paix there. Subsequently came the peace congresses of London in 1843 , Brussels in 1848 , Paris in 1849 , and Frankfort in 1850 , but each showed under what disadvantages they had to operate. London was out of the question because of its colonialism, despite the fact that Cobden and Bright, in their anti-Corn Law agitation, revealed what democratic trend existed among their countrymen. For that same reason the most important of these four congresses, that at Paris, was inconsequential, even though the dean of French liberals - Victor Hugo - presided, and no less than Richard Cobden, Emile de Girardin and Garnier-Pagès collaborated, with Minister of the Interior Lacrosse and Foreign Minister de Tocqueville sounding the welcome addresses to the delegates. Anglo-French intrigue, or diplomatically speaking, ententes, were nothing less than imperialistic schemes. Both Brussels and Frankfort did not inspire sufficient neutrality, nor did they render that cosmopolitan atmosphere for which Geneva had become known, notwithstanding the definite contributions in popularizing the ideas 
of armament reduction and a congress of nations made in the new Belgian capital and in the renowned free city of Frankfurt-am-Main.

By I 867 another peace congress was urged, for the Anglo-French colonial expansion programs were coming to an end, and while contemplating new capitalistic ventures, the other European powers, notably Austria-Hungary, Prussia and Italy, cast covetous eyes upon their neighbors' conquests. Then too, the revolutions of ' 48 , the Franco-Italian-Austrian War of 's9, the War of Italian unification of '6o, the Polish-Russian War of ' 63 , and the Prussian-Italian-Austrian War of ' 66 showed, if anything, that the tempo of wars was increasing, and that unless something was done at once the much-feared FrancoPrussian conflict of interests might erupt into a catastrophic conflagration for all Europe. Thus when in ' 67 the latter two powers disputed the right to annex Luxembourg, the French newspaper Phare de la Loire, under the inspiring leadership of Evariste Mangin, its editor, took the initiative and on May 5 called for an immediate congress "qui veut sincèrement épargner à l'Europe les horreurs de la guerre". And since it already explained its belief in a congress of nations to "end all threats to the peace" 1 the nature of its appeal was unequivocal. In addition, as a result of the initial meeting in Paris of those interested, the full title of the congress was to be the Congress for Peace and Liberty so that it would be differentiated from the previous ones, which, while advocating representation and arbitration by freely elected delegates, passively accepted peace dependent upon the status quo; the new congress wanted to attack the status quo, for in some cases it suppressed liberty and rendered only an ephemeral peace.

And to epitomize the congress the revolutionary and popular hero of the day, he whom George Sand referred to as "l'oriflamme de l'ère nouvelle" and whom Victor Hugo described as "un homme dans toute l'acception sublime du mot. Un homme de la liberté; un homme de l'humanité" - Giuseppe Garibaldi - was chosen as the honorary president. In fact the Phare in eulogizing him reiterated its general aims by writing that "ce nom est à lui seul le plus net des programmes. Il veut dire héroïsme et humanité, patriotisme, fraternité des peuples, paix et liberté". 2

But where was the congress to convene? Certainly not in Paris, where, besides the reasons already given, the new French law limited congregation to a mere twenty persons. Neither had the Phare forgotten that ever since 1849 when Garibaldi dared defend the Republic of Rome against the efforts of Pius IX and Napoleon III, who in turn was

1 „... mettre fin à toutes les contestations menaçantes pour la tranquillité des peuples...”

${ }^{2}$ Le Phare de la Loire, Paris, Io Août I 867. 
pressed by the French royalists and Catholics, Garibaldi was persona non grata in France; nor could it have been ignorant of the fact that when Alexandre Dumas sought to publish Garibaldi's memoirs he was compelled to send them to Méline, Cans and Co. in Brussels because the French publishers, fearing the wrath of their emperor, would only publish such expurgated editions as were inoffensive to Napoleon III. ${ }^{1}$ Consequently another cosmopolitan city, Geneva, the traditional home of the refugee, which certainly was not tainted with imperialism, was confirmed as the site. In July the definite dates of the congress were set for 9-I 2 September, thus permitting the delegates attending the International Workingmen's Association Congress in Lausanne on 2-7 of that month to attend also.

In Geneva the singular honor was deeply felt, and if the congress promised some daring resolutions the preparations under way in the former stronghold of Calvin were overshadowed by the celebrations planned for Garibaldi's arrival on September 7. By the $4^{\text {th }}$ of that month the city was already postered with billboards proclaiming that

"Genève, où la liberté règne; Genève, qui s'est émancipée jadis du joug ultramontain, applaudira à la vie héroïque, aux espérances sublimes de Garibaldi. Acclamer Garibaldi, c'est dire hautement que l'on veut pour les peuples le droit de se gouverner euxmêmes... Liberté nationale, émancipation du joug de Rome, voilà ce que signifie le nom de Garibaldi; voilà pourquoi les Genevois doivent l'acclamer...." 2

The evening of the following day the citizenry, as represented by all the political parties, was convoked at the Stand de la Coulouvrenière, the city's popular meeting place, to elect a Genevese reception committee worthy of their honored guest. James Fazy, the former political idol of Geneva, was elected president of a fifteen-member committee, which in turn issued its own proclamation acclaiming

“....l'homme le plus valeureux et le plus désintéressé de son siècle... l'homme qui personnifie les aspirations démocratiques et philosophiques de la génération nouvelle, et que, sous son égide, la famille genevoise tout entière réunie invoque ensemble la liberté."

Simultaneously the congress's manifesto, which had first been worked out by the Paris and Geneva groups and published on June I I, along

${ }^{1}$ Mémoires de Garibaldi par Alexandre Dumas, précédés d'un discours sur Garibaldi par Victor Hugo et d'une introduction par George Sand. Seule édition complète, interdite pour la France. Bruxelles, Méline, Cans et Cie (1861). 3 vols. $16^{\circ}$.

2 Billboards paid for by the Parti Indépendant de Genève. 
with its governing articles and its three-point program were published in all the newspapers. The program, stated in the form of three questions, was as follows:

"I ère Question. Le règne de la Paix, auquel aspire l'humanité, comme au dernier terme de la civilisation, est-il compatible avec ces grandes monarchies militaires qui dépouillent les peuples de leurs libertés les plus vitales, entretiennent des armées formidables et tendent à supprimer les petits Etats au profit de centralisations despotiques? Ou bien la condition essentielle d'une Paix perpétuelle entre les nations n'est-elle pas, pour chaque peuple, la liberté, et, dans leurs relations internationales, l'établissement d'une confédération de libres démocraties constituant les États-Unis d'Europe.

2e Question. Quels sont les moyens de préparer et de hâter l'avénement de cette confédération des peuples libres? Retour aux grands principes de la Révolution, devenant enfin des vérités; revendication de toutes les libertés, individuelles et politiques; appel à toutes les énergies morales, réveil de la conscience; diffusion de l'instruction populaire; destruction des préjugés de race, de nationalité, de secte, d'esprit militaire, etc.; abolition des armées permanentes; harmonie des intérêts économiques par la liberté; accord de la politique et de la morale.

3e Question. Quels seraient les meilleurs moyens de rendre permanente et efficace l'action du Congrès international de la Paix? Organisation d'une association durable des amis de la démocratie et de la liberté. La principale tâche du Congrès de Genève devra être d'arrêter le plan et de jeter les premières bases de cette association."

By the time the Congress opened, the organizational committee in Geneva headed by the Frenchman Jules Barni, the eminent translator of Kant and professor at the Academy of Geneva, had received in support of its program applications from 10,666 individuals, 4,480 of whom indicated no nationality and the rest were divided as follows: Swiss 2,71 $3 ;^{1}$ Germans and Hungarians 1,609; Frenchmen 1,006; Italians 442; Englishmen, Scotsmen, and Irishmen I 49 (including one Australian); Belgians ros; Russians 45; Poles 39; Americans (north \& south) 32, including Fisk of the New York Herald, a Mr. Philipps also of New York, a delegate of the American Peace Society named

1 Apparently by the time the Congress opened many more subscribed. "On comptait plus de six mille adhérents dans Genève et les environs”, states Fazy in his Mémoires de James Fazy, Genève, Editions Celta, 1947, p. 212 . Fazy was, among other things, president of the Institut de Genève's Sciences Morales et Politiques Department which took charge of all preparations. 
Cleveland from Philadelphia, a Lamb of Cincinnati, James Baven of Chicago, and a Dr. Esquierdo of Puerto Rico. Membership was open to anyone paying the small sum of twenty-five centimes, which also included admission to all sessions and the right to pose questions and vote. Thus a more democratic setup could hardly have been conceived; indeed, it resembled one giant New England town hall meeting. And among the better known who became members were Bakunin, Albert and Louis Blanc, Barthélemy, Emilio Castellar, Victor Hugo, Edgar Quinet, Carnot, Jules Favre, Jules Simon, Beales (president of the English Reform League), John Stuart Mill, Alexandre Herzen, General Bossak-Hauké, G. Ceneri (professor of Roman Law at the University of Bologna), and Garibaldi's faithful redshirts Alberto and Jesse White Mario, Frigyesi, Dolfi, Frapolli, Mauro Macchi, Dr. Riboli, Fra Pantaleo, Benedetto Cairoli, Vincenzo Caldesi, Pietro Delvecchio and Giovanni Basso, his secretary.

The presence of the Garibaldian contingent was fortuitous, even though they all favored the aims of the Congress. Garibaldi for months already had been making no secret of his intention to attempt again to oust the Pope and make Rome the capital of Italy. In fact, by September $\mathrm{I}$ the Journal de Genève, Geneva's largest newspaper, was reporting from its special correspondent in Turin that the rumors concerning Garibaldi's plans were general. ${ }^{1}$ Two days later the same journal reported the vociferous ovation given the General by his gathering redshirts at Orvieto, and even by the regular Italian troops stationed there, who shouted: "Long live Italian Rome! We want Rome!" But all was not in readiness for the putsch; for one thing, the necessary arms were lacking, and in order to resolve the difficulty Garibaldi had sent his English-educated son, Ricciotti, to England for the purpose of soliciting funds. In the meantime arrived the invitation from Prof. Barni in behalf of the organizing committee to come to Geneva where "votre présence serait le meilleur commentaire de notre programme." No mention was made of the desire to make him honorary president, nor could he have cared less. Putting first things first, he had to wait for Ricciotti's return in any case, then he certainly endorsed the Congress's program, in which, it undoubtedly came to him, he could enlist public opinion in his favor as regards his putsch for Rome. From the border of the Papal States he made for Geneva with a handful of faithfuls going via Florence and Milan, and passing through Domodossola and the Simplon Pass on Saturday September 7. En route other Garibaldians joined him. That evening he was due in Geneva, but as he passed through each Swiss town an ovation awaited

1 Journal de Genève, I Septembre 1867, p. 2, Dispatch from Turin, 28 Août. 
him, so that it was necessary to wire ahead that the group would arrive only at Sion, in the Valais, by 9:30 Sunday morning.

In Geneva everything was about ready for the visit of their distinguished guest. All the newspapers had published the order of the reception, beginning with the formation of a cortège at the Bastions, where all the Genevese societies were convoked to file behind the federal, cantonal and Italian flags, followed by the tambours corps and the foreign societies, and then to proceed along the fashionable Corraterie and the Rue du Rhône to the celebrated hotel l'Ecu de Genève and the Grand Quai. Here Garibaldi was to arrive by the lake steamer Simplon from Villeneuve, where the Genevese reception committee was first to greet the Italian tevolutionary and to accompany him to Geneva. From the quai he was to be escorted to his hotel on the other side of the lake, where the official reception was to take place from his balcony. The reception over, the cortège was to pass in review before their guest, proceed along the Quai du Mont-Blanc, the Rue des Alpes and Rue Bonivard, to be disbanded on the main thoroughfare, the Rue du Mont-Blanc. And with characteristic Swiss thoroughness the principal societies, like La Société Démocratique de la Ficelle, La Société de la Jeune Genève, and La Société Helvétique, down to the proud Union des Platriers peintres, published their own instructions in the press detailing their members to their places in the cortège. The Theiatre de la Ville de Genève, in honor of the event, announced its closing for three days until September 10.

Thus because of the unforeseen receptions en route and the telegram of the $7^{\text {th }}$ new billboards had to be posted over those previously announcing Garibaldi's arrival for the evening of that day. All preparations remained the same, it was explained, except that the cortège would take place of Sunday evening, the 8th, instead of Saturday, and that instead of the steamer Simplon meeting their guest at Villeneuve it would be a train group. Refunds for those who had wished to join in the reception by steamer would be made; the train group instead would leave Geneva at 9 A.M. Sunday. This was the first sign that all was not well in the preparations and that in fact some minority groups had arisen to sabotage deliberately Garibaldi and the Congress. As Charles Menn, the secretary of the organizational committee announced, ${ }^{1}$ the change was due to "la mauvaise volonté de l'administration du Simplon". The reason given by the navigation company for the cancellation was that the new date found the Simplon already engaged, hence the reception committee could not be accommodated. But the latter had notified the company of the change of date in time and had even entered into negotiations for the new date.

${ }^{1}$ Ibid., 8 Septembre 1867. 
In fact, the Société de l'Arquebuse et la Navigation, which had previously engaged the Simplon for Sunday, the 8th, had gladly surrendered its reservation in favor of the reception committee, ${ }^{1}$ and the steamship company had obliged by granting a reduced rate in view of the unexpected numbers to be carried, when a contrary order from within the company informed the committee that the Simplon, as well as their other two steamers, the Italie and the Mercure, were no longer available. ${ }^{2}$

When the special reception train composed of two cars of second and third class "à l'américaine", plus a wagon-salon attached in Lausanne for Garibaldi and his entourage, arrived in Villeneuve just after 2 P.M. it found that the Garibaldi train from Sion had preceded it by a half hour, and that the latter's passengers were waiting at the lake-town's Hotel Byron, near the famed English poet's scene of imprisonment. The Geneva group, some Iso, including representatives of the organizational committee, hurried there and upon seeing their idol a general cry of Vive Garibaldi greeted him. Émile Acollas, of the Paris Committee, extended the official welcome and after a brief exchange of greetings Garibaldi was returned to the railroad station in an open carriage for the benefit of the populace who excitedly lined the way. At one point a voice cried:

"Vive la république européenne!" But the veteran republican campaigner, conscious of Swiss neutrality as well as its generosity, merely stood up in his carriage and waving his grey felt hat with difficulty contented himself by answering:

"Vive Genève, la Rome de l'intelligence!"

With awe they gazed upon the man they had learned to love from his feats in South America, the Varesato, Rome, Sicily, and the heartrending Aspromonte affair in 1862. But he looked older than his 62 years, for he walked with difficulty and his right hand lay almost lifeless at his side with rheumatism. His general appearance was one of suffering, although as one caught the gleam of his eyes he comprehended how the fearless warrior dared risk another bout with the Papal troops. Otherwise, he was just as they had seen him reproduced in the papers for twenty years, standing proudly, with his impressive leonine head and red-shirted broad chest standing out against his light blue trousers and inevitable poncho à la gaucho flung over his shoulders. From his right pocket, where he carried a large silver watch, hung his only decoration, a steel chain.

The train ride to Geneva surprised everyone by the size of the 1 Annales du Congrès de Genève (9-12 Septembre I867), Genève, Veresoff \& Garrigues,
I 868, p. I 04 .
2 Journal de Genève, Ir Septembre 1867. 
crowds which met the group at every town, for it had been learned that most of the people were uninformed of the change in schedule and were still crowding the quays along the lake since early the previous day. At Lausanne more than I 500 people thronged the train station as the train stopped momentarily and the news spread that Garibaldi was aboard. It took fifteen minutes before it could leave again. Fifteen kilometres away at Morges, a typical Vaudois reception took place which saw Garibaldi bringing the wine of honor, for it was the season of the vendange, to his lips to the accompaniment of three music societies and the hurrahs from the town officials and citizenry - all within the confines of the little station. Ironically, the honored guest was a confirmed teetotaler. After a brief welcome address by the mayor, Garibaldi thanked his kind hosts and the train chugged on to St. Prex and Allaman, where similar welcomes took place. In the latter town a man jumped on to the train platform and yelled:1

"Général, les peuples comptent sur vous!"

"Et ils n'ont pas tort", shot back Garibaldi. The crowd roared approval.

At Bursinel, the weary visitors took time out to wash up and have a snack, since at Villeneuve where a repas was planned for one hundred, that is, for the guests and the Genevese, it proved insufficient when one hundred and fifty arrived on the Geneva special alone. In Céligny, the enclave on the border of the canton of Geneva, the excitement even quickened as the children insisted that they be carried up to Garibaldi so that they could touch him. Particularly impressive here were the bouquets he received.

But if the celebrations in the Valais and Vaud were unprecedented, that in Geneva was beyond the wildest expectations. The Journal de Genève represented unanimous opinion in saying that "jamais personne n'avait été honoré par elle [Geneva] jusqu'à ce jour" as was Garibaldi. ${ }^{2}$ When the cortège, which counted some six thousand participants, reached the railroad station "une véritable mer mouvante de têtes s'agitait déjà sur la plateforme, les escaliers, les rampes de la gare et emplissait les extrémités de toutes les rues qui y aboutissent... La foule était telle que le cortège ne put se faire une place suffisante pour se développer, et que la plus grande partie dut faire halte..." But the Journal failed to mention two more incidents which unfortunately affected the Congress adversely. First, when during that Sunday afternoon of September 8th the members of the Congress gathered in order to greet Garibaldi upon

1 La Suisse Radicale, Lundi 9 et Mardi ro Septembre 1867, Genève.

2 Supplément du 9 Septembre I 867. Also, L'Illustration, Journal Universel, Paris, Samedi 21 Septembre 1867 , p. 182. 
his arrival, they were surprised to find that the French-owned station ${ }^{1}$ of the Paris-Lyon-Méditerranée Railroad, Geneva's main station, claimed extraterritoriality and barred them from its premises. Displeased, but undaunted, the members stood by until a little after six o'clock that evening when the salvos from four cannon, lent especially by the militia, heralded the arrival of the much-awaited train. The guards were swept aside by the irresistible crowd, now joined by the frustrated paraders.

At this time occurred the more serious incident of the two mentioned above. As Garibaldi was literally carried by the enthusiastic throng from his wagon-salon to a luxurious carriage à la daumont ${ }^{2}$ standing nearby, which had been placed at the disposition of the Central Committee by the wealthy Hungarian refugee Csàky, it was seen that the carriage seated but three. obviously Garibaldi, his personal physician Riboli, and a third person, logically Prof. Barni, as president of the Central Committee. But James Fazy, perhaps as president of the Geneva Reception Committee, moved to occupy the seat instead, whereupon other committee-men standing alongside restrained him while Prof. Barni took the seat intended for him. As expected, such a scene, brief as it was, had its reverberations. Fazy soon became, along with the Journal, which he had founded, the principal detractor of the Congress.

The carriage then made its way with great difficulty through that "masse impénétrable... jusqu'au lac" and the exclusive Quai du MontBlanc where was located the suite offered by the Banque Suisse as Garibaldi's residence during his stay. Incidently the suite was in the Hôtel Fazy, which only recently had been acquired from James Fazy, who still owned most of that select Bergues area. It was at the junction of the Rue du Mont-Blanc and the quai of the same name, today the fashionable Hôtel de Russie. After a few moments Garibaldi appeared on the first story balcony with Fazy and Wessel, the vice-president of the Reception Committee. The view before them was inimitable, with the gesticulating masses stretched along the quai as far as the eye could see, Lake Leman, ${ }^{3}$ and the majestic Queen of the Alps - the MontBlanc-looming in the background. Fazy opened the official welcome to the city by saying:

"Vous voyez ce peuple, général, vous entendez ses acclamations; je n'ai pas besoin de paroles pour vous expliquer quels sont ses sentiments, son cœur bat à l'unisson du vôtre; car ce peuple, comme vous,

1 The Geneva railroad station, along with all foreign trains operating within Switzerland, did not become the property of the Swiss Confederation until January I, I913.

2 With four horses and two postillions.

${ }^{3}$ Commonly called Lake Geneva. 
est dévoué à la liberté et à la démocratie." Wessel followed in a similar vein for a few minutes, but his words were lost among the tumultuous crowd, until another salvo of artillery announced that Garibaldi would speak. A roar of acclaim met the cannon-shot, then there was complete silence. In his resonant, clear voice Garibaldi began:

"Ce n'est pas la première fois que je me suis trouvé dans le cas de témoigner ma gratitude au brave peuple républicain de l'Helvétie. En I 848, quand l'Italie, mon pays, était malheureuse et gémissait sous le joug, que mes amis et moi étions proscrits par les tyrans, ici, sur ce sol sacré de la liberté, nous avons cherché et trouvé un asile...

And in another minute he struck the chord which had determined his every action for the past twenty years:

"Ici, vos ancêtres ont eu le courage d'attaquer des premiers cette pestilentielle institution que l'on appelle la papauté.(Interminable acclaim). A vous, citoyens de cette cité de Genève devenue si magnifique, qui avez porté les premiers coups à la Rome papale, à vous ce n'est plus aujourd'hui l'initiative que je demande, mais je vous demande de compléter l'œuvre de vos ancêtres, lorsque nous donnerons les derniers coups au monstre! Il y a dans la mission des Italiens, qui l'ont si longtemps gardé, une partie expiatoire; nous ferons notre devoir: nous l'abattrons. Pour cela, votre concours peut être nécessaire, je l'espère! (Acclaim.) Eh bien! ne trouvez-vous pas maintenant qu'il y a de l'impertinence dans mes paroles? (Non, non. Bravo, bravo! point de pouvoir temporel! Rome aux Romains!) 1

Alors je vous dirai encore quelque chose. Vous trouverez peutêtre plaisant que Garibaldi soit venu à Genève pour recommander la concorde. Et cependant, je vous la recommande, parce que la concorde entre les hommes de la liberté sur le sol helvétique représente aussi la concorde des hommes de la liberté dans tous les pays. Votre concorde est donc une chose d'un intérêt universel. Mais si votre liberté était jamais menacée, nous aussi, hommes libres des autres pays, nous voudrions venir porter à côté de vous la carabine pour sa défense. (Acclaim). Adieu! adieu donc! Je vous remercie du cœur de votre excellente réception. Adieu!"

Thus Garibaldi spoke as frankly as everyone expected him to, and in so doing sounded the keynote of the Congress - the actual threats to the peace - upon his very arrival in Geneva. He now withdrew from the balcony while the crowds cheered and bands struck up Garibaldi's Hymn, the war song composed expressly for his Cacciatori delle Alpi

1 Charles Lemonnier, La vérité sur le Congrès de Genève, Berne et Genève, Veresoff et Garrigues, 1867, p. 14; and Annales, op. cit., pp. I I 2-1 I3. 
in 1859 . Subsequently fanfares and national airs of all the countries of Europe followed below the balcony, but Garibaldi came out no more; instead he supped on a piece of bread and some grapes, ignoring a sumptuous dinner prepared by his hosts.

The next day, Monday September 9 at two P.M., the Congress opened before some six to eight thousand members and spectators at the Palais Electoral, today the Salle du Conseil Général, near Place Neuve, as Garibaldi entered the vast auditorium and everyone rose to his feet in respect. When all were seated again the Liederkranz male chorus of one hundred voices impressively intoned a Hymne de la Paix from its stand in the gallery. Prof. Barni then, as temporary president, gave the opening speech by emphasizing the principal theme of the program the incompatibility of Caesarism and military monarchies with peace. Acollas, the Parisian lawyer and member of the initiating committee, all but named Pius IX and Napoleon III as the public enemies No. I and 2, while a M. Perron, representing the labor unions of Geneva, assured its solidarity and hoped that the Congress "ne reculera pas devant l'emploi des moyens propres à assurer la liberté en Europe." James Guillaume, the Swiss anarchist and biographer of Bakunin, now representing the International Workingmen's Association, however, added the socialist viewpoint that "pour arriver à supprimer la guerre, il ne suffit pas de licencier les armées, mais qu'il faut encore modifier l'organisation sociale dans le sens d'une répartition toujours plus équitable de la production". Thus the economic angle entered the picture as well as the political, but because of criticism and the inopportunity of the matter at that session it was tabled for later. Instead the regulations governing the Congress were presented for adoption and passed. The adoption of the program, however, came only after a determined opposition was made by the Balois, Schmidlin, the Director of the Central-Suisse Railroad. To be sure, most everyone was surprised at this about-face when for months already the program had been publicized and freely approved by the press; nevertheless, to people like Barni, the persecuted professor who was forced to flee France, and Acollas, intervention by the police or by vested interests was not unexpected. "Nous ne voulons employer que des moyens pacifiques et légaux”, insisted Schmidlin, “...la Confédération helvétique est petite et faible; elle ne peut espérer qu'on respecte ses droits que si elle respecte ceux des autres Etats... Ce n'est donc pas à nous à changer ou à juger les institutions des autres nations. C'est le droit de ces nations elles-mêmes. Du reste, les peuples ont le gouvernement qu'ils méritent..." Obviously, from such a discordant opinion, one wondered why such an individual bothered to attend the Congress; 
apparently he had never heard of, or refused to admit, that such despots as Napoleon III or Pius IX came into power by usurpation and that the sole means of destroying their tyrannic control was by extralegal means. For a moment it looked as if the matter would be passed over, until Fazy followed Schmidlin and assumed a somewhat similar attitude. Indeed, one could hardly fail to reflect upon the change that had come over the Swiss officials. "Écartez ces deux points [Questions $I$ and 2 of the program] et occupez-vous... du troisième point, qui concerne l'organisation permanente du Congrès", proposed Fazy. In other words, he would merely set up the machinery for perpetuating the status quo, the very antithesis of the purpose for which the Congress was initiated in the first place! And as if to recall to mind the Congress's will to change matters, the Parisian lawyer Albert Fermé took the floor and pointed to the eagle mounted on the French flag just over the sign $P A X$ and directly above Garibaldi's head. "Je me demande et je demande par quel singuliers éclectisme on a pu concilier cette étrange réunion", he exclaimed vehemently. "A bas," cried others, "l'aigle ne représente pas la France... c'est l'oiseau de proie de Rome impériale." But the opposition was beginning to show itself and yelled back defiance. It was at this point that Barni, as acting president, was determined to settle once and for all the program by offering to have the objectionable Questions I/ and 2 revised, or even withdrawn, if that was the wish of the majority. And with that show of democratic procedure the vote on the program was taken; to everyone's surprise, it was voted overwhelmingly, without the least objection.

As both sides relaxed after that intense bout, Garibaldi asked for the floor. He would have no misunderstanding as to why he came to Geneva. So accepting the kindness of the chair that he speak from his place, because "les suites de ses glorieuses blessures l'empêchant de monter à la tribune", he explained that he was not of the dissenter's (Schmidlin) opinion. "Si", he hypothesized,

"à la vue d'une personne qui se noierait dans les flots de votre lac, mes enfants me demandaient: 'Devons-nous aller à son secours, est-ce qu'elle le mérite?' - Je répondrais: 'ne calculez rien, n'appréciez pas ce qu'elle vaut, sortez-la du danger, aidez-lui.' (Like thunder, bravos and vivas reverberated throughout the auditorium.)

De même, je ne suis point de l'avis de ceux qui disent: 'les peuples n'ont que ce qu'ils méritent; chacun pour soi, chaque pays pour lui-même.' (Again a thunder of agreement, characterized this time by Non! Non!) Au contraire, je conseillerais toujours, chaque fois qu'une personne se trouvera en péril, de la sauver, quoi qu'il en coûte; on le doit.". (Again a thunder, this time Oui! Oui!) 
Then he went on at length, refusing at one point to define despotism since he believed that everyone knew what it was - "le mensonge, le fléau de l'humanité." And to combat it there was needed only the fratérnity of peoples. Thus, in so saying, he outlined his propositions for founding their organization upon a more permanent peace. He only apologized for so precipitatedly drawing up his ideas, for as he said, "je vais quitter bientôt cette terre d'asile et de liberté". ${ }^{1}$ The propositions were:

"I. Toutes les nations sont sœurs.

2. La guerre entre elles est impossible.

3. Toutes les querelles qui peuvent survenir entre les nations seront jugées par le Congrès.

4. Les membres du Congrès seront nommés par les sociétés démocratiques de tous les peuples.

5. Chaque nation n'aura qu'un vote au Congrès, quel que soit le nombre de ses membres.

6. La papauté, comme la plus nuisible des sectes, est déclarée déchue d'entre les institutions humaines..."

With this, general acclaim was heard, although not without some resentment; whereupon Garibaldi felt obliged to remark:

"Je ne sais si l'on dira que je m'aventure un peu trop en formulant un tel article. Mais à qui pourrais-je communiquer ma pensée, exprimer librement mes idées, si ce n'est pas à vous, peuple libre et vraiment libre?"

The assemblage assured him, so that he picked up his manuscript and continued:

"7. La religion de Dieu est adoptée par le Congrès..."

But some adverse remarks cut him short again. And once more, in an understanding voice, he proffered:

"C'est une opinion que je vous soumets."

Everyone seemed to understand and urged him on.

"7. La religion de Dieu est adoptée par le Congrès, et chacun de ses membres s'oblige à la propager sur la urface du monde..."

At this point Baron de Ponnat, of France, interrupted: "De quel Dieu parlez-vous?" To which Garibaldi answered:

${ }^{1}$ A point ignored by Garibaldi's detractors; see letter wtitten from Genestrello, at the end of this article. 
"Je vous dois un mot d'explication. Religion de Dieu, religion de la vérité, religion de la raison, sont synonymes". ${ }^{1}$

There was a general applause and Garibaldi resumed his propositions.

"8. Le Congrès consacre au sacerdoce les hommes d'élite de la science et de l'intelligence.

9. Propagande de la démocratie par l'instruction, l'éducation et la vertu. Ce n'est point là une opinion d'aujourd'hui; la république est le gouvernement des honnêtes gens. Si on le contestait, il suffirait de faire remarquer qu'à mesure que les peuples se sont corrompus, ils ont cessé d'être républicains. (Great applause.) Io. La démocratie seule peut remédier au fléau de la guerre par le renversement du mensonge et du despotisme.

I I. L'esclave seul a le droit de faire la guerre contre les tyrans."

Garibaldi now handed in his manuscript amid a tremendous applause. In closing he discussed a few of the propositions he had made, particularly those concerning religion, which he admitted having observed that they had not pleased everyone. "Malheureusement", he added, "il en est ainsi pour cette question. Toutefois, je suis persuadé qu'il n'y a personne qui puisse détacher la question religieuse de la question politique. Je ne veux pas en donner pour preuve les guerres religieuses qui ont ensanglanté le monde. J'en donnerai une preuve récente: la guerre de Crimée." And in a simple manner he explained how that great conflict, which involved four nations and cost no less then 200,000 lives, was in fact caused by two priests, one Greek and the other Catholic, whose fierce pride led them to dispute each other's rights to conduct religious services in the Temple of Jerusalem. "Je le dis", he concluded, "on ne pourra remédier aux malheurs du monde sans remédier aux abus de la prêtrise."

With that Barni proceeded to the final business of the first day, the election of the Congress's officers, and in a magnanimous gesture to please the Swiss he nominated the Bernese lawyer and State Councillor, Jolissaint, as president. It was accepted and voted unanimously, as was Barni to the vice-presidency. At four o'clock the session was adjourned, whereupon the assembly surged over to the platform to

\footnotetext{
${ }^{1}$ From here on through Article ro Garibaldi abridged. The more complete listing of propositions were those he submitted in writing before the Congress opened. In that listing the original 8 th, gth and roth articles were: 8 . The ministry (priesthood) of revelations and of ignorance to be supplanted by the ministry of the divinity of genius, science and intelligence. 9. Propaganda to be undertaken to promote the moral aspects of democracy as manifested in honest people. ro. Propaganda for the religion of God to be by instruction and education.
} 
congratulate Garibaldi and to accompany him to his residence at the other end of Geneva.

The next morning at nine o'clock Garibaldi paid a visit to Count Bossack-Hauké, the hero of the 1863 Polish revolt against Russia, who now in exile was a member of the Polish delegation to the Congress. On descending from his carriage in front of the modest house sheltering the Polish general and his family on the Rue de Lancy in Carouge, Garibaldi exclaimed:

"Général, c'est à un ami que je viens rendre visite." And as a crowd pressed around, added: “Je veux que l'on sache que, si l'Europe jésuite et diplomatique vous a abandonnés, la démocratie ne vous oubliera jamais." They shook hands like old friends and entered the Hauké apartment; in fact, they were old friends although they had never met, for Garibaldi had collaborated in the ' 63 abortive attempt by sending his famous Nullo Brigade to Poland, more Garibaldians who were to die fighting for self-determination and republicanism in a foreign land. Nor did Bossack-Hauké forge this friend in deed, for only four years later, during the Franco-Prussian War, he was killed in action while leading his First Brigade in Garibaldi's Armée des Vosges. Only this time their cause was republican France.

The second session of the Congress which took place that afternoon was reasonably calm although several incidents presaged an explosion in the making. First Garibaldi, in answer to a request received that morning from the Société des Rationalistes of Geneva, elaborated upon his ideas concerning religion of the previous day, in a letter read by Barni. It stated:

Mon cher Barni,

"Genève, ro Septembre 1867.

La confédération de toutes les libres démocraties, que vous avez proclamée hier, marchera lentement, mais marchera. L'organisation d'une association universelle et durable des amis de la liberté siégeant à Genève, en permanence, sera un beau resultat pour le Congrès international de la Paix.

Terminons notre mission démocratique pour le monde entier en proclamant: La religion universelle de Dieu, substituant aux prêtres Arbuès et Torquemada, le sacerdoce des Leibnitz, des Galilée, des Rousseau, des Arago, des Newton, des Quinet, etc.

Nous aurons ainsi déblayé le sentier qui doit nous conduire à la fraternité des peuples, et cimenté d'une manière durable le pacte de la paix universelle.

G. Garibaldi." 
Undoubtedly to the Genevese rationalists Garibaldi's inclusion of Leibnitz, with the latter's rationalistic conception of God, must have been most gratifying, and singularly disconcerting to the orthodox Christians who were first shocked only two days previous at the reception. Incidently the erratic Russian novelist Dostoyevsky, who happened to be at the Congress, was one of these; ${ }^{1}$ he had long admired the Italian revolutionary but his morose nature, embittered by years of imprisonment in Siberia and nurtured by religious orthodoxy, resented these remarks, Some dozen speeches followed, the highlights being those delivered by Quinet, Goegg, Lt. Col. Frigyesi and Bakunin. Quinet, the exiled French historian who bitterly assailed the Catholic Church for the failures of the revolutions in France, lamented the loss of conscience among men; Goegg, the ex-Minister of Finance of the Republic of Baden, decried the domination of priests - "le phariséisme moderne" - throughout Europe; while Bakunin, the notorious Russian anarchist who had come from Lausanne and the Marxist I. W. A. Congress, where he opportunistically proclaimed his own doctrines, belittled the present initiative as well, in preference for his ideas on the destruction of centralized government and the federation of communes instead. ${ }^{2}$ But if these speakers were well received for their intellectual appeal Frigyesi, one of Garibaldi's Hungarian volunteers, won the hearts of everyone when after pleading for the end of "hiérarchie militaire" and the substitution of "guerres des peuples contre leurs oppresseurs" in its place, took out from his pocket a handful of his gallantly-won medals and handing them to the president asked him to sell them, the proceeds to go for the purchase of some "instrument de la paix", that is, "quelque livre utile au peuple."

Now that underlying current of opposition which had manifested itself in cancelling the reception committee's engagement of the Simplon, in the Compagnie du Paris-Lyon-Méditerranée's refusal to accommodate this same committee in its Geneva station, and in Schmidlin's no-action proposal, was erupting in seriousness. Antoine Carteret, one of the leaders of the Genevese Radical Party, took the floor on the pretext of a point of order before others previously slated to speak and claimed in a thundering voice that Fazy's proposal to eliminate Questions I and 2 had been deliberately by-passed and not given the possibility of a vote. The Congress could hardly have been more astounded, even though from the right and gallery it was evident

1 A. Yarmolinsky, Dostoevsky, his Life and Art, New York, Criterion Books, I957, pp. 243-245; also, Dnevnik A. G. Dostoevskai, r867, Moscow, 1923.

2 Bakunin's extreme proposals were responsible for at least one resignation from the Congress; see Pierre Dolgoroukow, Lettre à M. le Président du soi-disant Congrès de la Paix par le prince Pierre Dolgoroukow, Genève et Bâle, H. Georg, 1867, 16 $6^{\circ}$, 2 p. 
that a certain group of local spectators were backing Carteret's irresponsible assertion. The president could only remind the speaker that the program had been unanimously adopted, but that, if desired, the proposal could be presented for adoption at a later session. Whereupon Carteret took his seat again, to the disquieting support from the gallery. In fact it was only the beginning, for when a moment later it was announced that the Swiss had finally formed their delegation (the last to do so), and Wessel presented a list of seven fellow Swiss, including himself, nominated by their countrymen to represent them on the Directing Committee, he made his acceptance dependent upon Fazy's, who was also nominated. "...étant homme de paix, je me fais un devoir", strangely remarked Wessel, who in Genevese life headed the Independant Party in opposition to Fazy, "de subordonner mon acceptation à celle de M. James Fazy". And at this point the once popular idol of Geneva, Fazy, took the stand amid a certain applause and announced:

"Messieurs, je regrette de ne pouvoir accepter la nomination faite ce matin au nom des Suisses présents au Congrès de la Paix. J'ai, pour ce refus, des raisons personnelles qui n'ont pas trait à l'organisation du Congrès."

Suspicious as this refusal was the president could only accept both refusals, and it being already 5:30 adjourned the session until the following afternoon. Just as the first day, the crowd moved towards Garibaldi to acclaim him; not a single hostile remark was heard about him or the Congress.

A few hours later he addressed the following farewell to the crowd gathered at his hotel and on the Quai du Mont-Blanc, for as he had announced upon his arrival in Geneva, as well as on the opening day of the Congress, ${ }^{1}$ he would be leaving the next morning: ${ }^{2}$

"Je profite de cette occasion pour adresser mes adieux au peuple de Genève. Je vous parle avec un cœur rempli d'émotion. Je suis profondément touché de l'accueil que m'a fait l'hospitalière et généreuse Genève, et me sépare de vous avec le même regret que de ma propre famille. Les institutions qui sont le fondement de la société de Genève nous serviront d'exemple.

Honneur et prospérité à ce peuple généreux et gentil! Merci, mes amis. Adieu. Bonsoir. Adieu."

Soon after, that evening, the opposing force let itself be known through

${ }^{1}$ See p. 16, footnote 1 and the Genestrello lettet at end of atticle.

2 Annales, op. cit., p. 203. 
the following letter directed to Geneva's executive body, the Conseil d'État: ${ }^{1}$

Genève, le ro Septembre i 867.

"Messieurs,

Les soussignés, citoyens suisses et genevois, viennent en leur qualité de catholiques protester hautement contre les faits qui se passent sur notre sol suisse et dans notre république et canton de Genève.

Sous le prétexte du Congrès de la Paix, nous avons entendu des paroles qui sont une excitation à la guerre civile, une violation du respect dû à la conscience de la moitié des habitants du canton de Genève.

Nous devons à notre honneur de faire une protestation publique et de manifester hautement notre intention de voir toutes nos libertés, et surtout nos libertés religieuses, respectées.

Notre neutralité est le gage de notre sécurité pour l'avenir, comme elle l'a été pour le passé.

Confiants dans votre sollicitude pour la paix et la bonne harmonie entre les citoyens, nous espérons que, par votre influence, les étrangers n'abuseront pas de notre sol hospitalier pour injurier nos convictions.

Veuillez agréer, etc."

( 32 signatures follow) But this was only a minority group, even among the Catholics, which protested, for two days later, on September 12, the Journal de Geneve felt obliged to publish the following letter from Catholics who approved of Garibaldi and the Congress, as follows:

"Chêne-Thonex, le i I Septembre i 867.

Monsieur le Rédacteur,

Nous lisons dans le numéro de ce jour de votre journal une lettre adressée au Conseil d'État par trente-deux citoyens ca-

\footnotetext{
${ }^{1}$ Régistre du Conseil d'État, 2 me semestre, I867, 420, p. 213 . Also handbill: Adresse des Catholiques à S. G. Mgr. l'Évêque d'Hébron, Genève, 1867 . „Nous nous sentons pressés de venir auprès de vous protester contre le langage outrageant qu'a fait entendre dans notıe ville l'ennemi déclaré de la papauté... la Sainte Église, qui est la pattie de nos âmes." Subsequently Mgr. l'Évêque d'Hẻbron, commonly called Bishop Mermillod, wrote a detailed letter to Pius IX protesting Garibaldi and the Congress, and although this letter remains unavailable in the Vatican Archives the following letter from other Christians, including Catholics, protested Mermillod's letter to the Pope: Lettre au Pape pour servir de Supplément à celle que lui a éciite son vénérable Frère Gaspard, évêque d'Hébron, Auxiliaire de Genève, dans le mois de Septembre 1867 , Genève, Impri. partic. de C. L. Trivier, $1868,24^{\circ}$, 10 $\mathrm{p}$. plus documents.
} 
tholiques en protestations contre les événements dont notre sol est actuellement le théâtre.

Au nombre des signataires il en est onze citoyens de la commune de Chêne-Thonex. Cette proportion a lieu de nous étonner, et comme nous ne voulons pas que l'on se méprenne sur les tendances de la majorité de la population de Chêne-Thonex, nous déclarons que nous sommes prêts à fournir cent signatures de citoyens nés catholiques sacbant lire et écrire qui approuvent sans réserve le programme du général Garibaldi et l'idée qui préside au Congrès de la paix; et que ces cent citoyens nés catholiques sont prêts à seconder de tous leurs moyens, toutes les tentatives qui seront faites dans le but d'affranchir les peuples de la tyrannie des consciences et de toutes les superstitions.

Agréez, etc.

$$
\text { J. Gielly, François Baud, and ro others." }
$$

Unfortunately the isolated reactionaries had institutional support and thus lost no time in allying themselves with each other in the common cause, or as the jurist Lemonnier, who was present, said: 1 "Entre l'orthodoxie protestante, l'intolérance catholique et l'irritation des banquiers et des capitalistes, l'alliance, habilement négociée, fut vite conclue." This despite the fact that the president of the Conseil d'Etat answered the Catholic protest by reminding them "que le droit d'association est garanti dans notre canton; que chacun, en conséquence, peut émettre ses opinions sous sa propre responsabilité, mais que le Conseil d'État fera respecter les lois qui garantissent la liberté des cultes, s'il y était porté atteinte sous une forme quelconque." Needless to say, religious liberty was not being attacked in the Congress, in fact it was being strengthened by an appeal to individual convictions; what was being attacked was the tyranny over people's minds being exercised in the name of religion by certain despots. Two days later the Radical Party's journal, which Fazy now oddly repudiated as "cette feuille malveillante", realized this all too well and was the first of the Geneva papers to protest the Catholic action. ${ }^{2}$

At nine o'clock in the morning of Wednesday September I I Garibaldi and his immediate followers took leave of their hosts at the rail station of the Paris-Lyon-Méditerranée, bound for Italy. The send-off was as warm as the reception upon arriving, but by eleven o'clock as one moved down the Mont-Blanc he was conscious of a more austere

I Lemonniet, op. cit., p. I9.

${ }^{2}$ La Suisse Radicale, I 2 Septembre 1867 : „C'est mal comprendre la liberté que de ne pas respecter celle de la conscience..." 
atmosphere than had prevailed during the three previous days. Many of the banners decorating Geneva, traditional bunting for its gala occasions, were being removed as bewildered crowds clustered about posters put up by the protesting Catholics. Conversations ensued concerning instructions being imparted by some church authorities, particularly Catholic Bishop Mermillod, against "les spectres du socialisme et de l'athéisme" pervading the Congress. Worst of all were the dispatches the reactionary part of the Genevese press were sending abroad, especially to Paris newspapers, that Garibaldi had become convinced of the imminent collapse of the Congress and fled.1

At the Palais Electoral the friendly atmosphere had changed too. Only Garibaldi's chair, reverently kept vacant, reminded one of the two more fraternal previous sessions. Many newcomers appeared for the first time, provoking arguments and insulting guests. Acollas was surrounded and threatened. A rumor even circulated that men armed with clubs had been brought to Geneva, supposedly to take care of the "irrespectueux" foreigners. The session itself that afternoon opened orderly enough but as time passed it became obvious that with the hired tapageurs and meneurs heckling from the gallery, reinforced by such Swiss orators as Carteret, Amedée Roget, and Dupasquier, led by the ubiquitous Fazy, sabotaging from the floor, it was a race as to which of the two factions - the liberal, action-bent Republicans or the reactionary Church-bankers - capitalist alliance of Geneva - would dominate the Congress. Fortunately the liberals perceived in time that the obstructionists' plan was to stall at any cost the adoption of any resolutions, especially those concerned with the creation of the permanent organs of the Congress, first by the introduction of sufficient numbers of affidés, or stooges, in the assembly so as to insure majority votes against any such enactment, and secondly, if that failed, to prolong the time allotted to general speeches to such an extent that the Congress would conclude its four-day meeting without having provided for its permanence. When no less than seventeen communications and speeches had taken place Jolissaint, as president, moved to have the resolutions of the program, already adopted in French on the first day, read now in German and discussed in order that they would be ready for voting the next day, the last of the Congress. But Roget and other Fazysts objected on the grounds that such action should not be entertained before the others had had their turn to speak. Jolissaint relented and the speeches continued. After only one more speech, that of Dr. Karl Grün of Germany, Jolissaint, in an attempt to placate the Fazysts, gave the floor to Roget, even though it was not yet his

1 L'Illustration, Journal Unlversel, Paris, op. cit., p. I82. 
turn to speak. Immediately the latter indirectly accused the Directing Committee of failing to have the Swiss take part in the drawing up of the program already adopted. When a volley of answers from the assembly came back that it was the fault of the Swiss for delaying so long in forming their delegation, Roget joined his resignation to those of Fazy and Wessel. More effective, however, was Prof. Barni's explanation that in fact it was the Geneva Committee which first prepared the program and only subsequently submitted it to the Congress for approval. After three more speeches cloture was again proposed in order to get on with the specific proposals, but Fazy himself now intervened. Again Jolissaint relented, only this time he submitted the matter to a vote. Apparently the opposition was growing, for the motion to curtail further speeches was not carried. Hence, five more speeches took place at the end of which the assembly saw Dupasquier of Neuchâtel, even attack republics for their lack of peace. Referting to the United States, he cried: "Elle a fait quatre années de la plus horrible guerre qui ait existé, si ce n'est pas dans un but d'oppression..."

At this point Hector Varela, the Minister of the Republic of Venezuela to Paris, took the floor to enlighten the would-be attacker of republicanism by narrating the salient facts of American growth under that form of government. He was wildly acclaimed. And on this more pleasant note, not that the opposition had subdued its tone any, Jolissaint adjourned the session until nine o'clock the next morning. It was already six thirty in the evening and most everyone was anxious to get away from the hectic session. For the first time at closing some insulting remarks were heard as the crowds filed by the Directing Committee. "Eh bien, l'on balayera le Congrès!" they uttered overtly.

That evening the reactionaries Fazy, Roget and Golay rallied their forces for the all-important day which was to follow. Church groups, that is, those inimical to the Congress, for on the whole most of them approved along with the majority of the Genevese, summoned their parishioners to assembly for a final protest. At the historic Stand de la Coulowrenière, where Fazy only six days before had led a fifteen-man committee in inviting Garibaldi, "l'homme qui personnifie les aspirations démocratiques et philosophiques de la génération nouvelle", now harangued a crowd to "balayer le Congrès". 1

"Jetez-les dans le Rhône!" roared back the incited mob, as passersby began to gather until some six hundred were present. When at length some of the latter voiced disapproval of the speakers, they were

${ }^{1}$ Lemonnier, op. cit., p. 23; Annales, pp. 266-267. 
violently silenced, although one worker dared shoud back at Fazy who was attacking the visitors and defending Popery: "Laissez-nous la paix avec votre pape, avec vos calottins... Vive Garibaldi!" He did not escape the displeasure of the crowd, however, and was chastised. Fazy then made a feeble attempt to calm his followers, less they be considered more violent than the Congress members, but in reality spurred them on in this skilful, political manner:

"Il était vrai que les Suisses n'étaient pas représentés au Congrès, que plus de quarante orateurs avaient été à dessein inscrits avant moi, qu'on voulait m'empêcher de parler, qu'il faut donc garantir la sécurité du canton, fermer la bouche à ces déclamateurs ignorants et vains..."

Indeed, one might well have wondered who was the vain one, if not he himself, for having resented the Congress's democratic Regulation No. 5, which stated that "les membres qui voudront prendre la parole sur l'une des questions à l'ordre du jour se feront inscrire au bureau; ils seront entendus dans l'ordre de leur inscription." More than likely this "slight", coupled with that which occurred upon Garibaldi's arrival when the seat of honor in the Csàky carriage alongside of Garibaldi was given to Prof. Barni instead of him, was responsible for driving Fazy into the hands of the reactionary Christians and capitalist interests. The once proud political idol of Geneva, who had tried in vain to climb back into power during recent years, was apparently now currying favor with the rightist elements. But alas, he only hurt his reputation by so doing, for the more consequent of the Genevese could not forget that their James Fazy was the same scion from one of Geneva's wealthiest calico goods producers, who in 1827 left to join Lafayette in Paris in the move against absolutist Charles X, participated in the Revolution of July 1830 , and who upon returning to Geneva founded the inspiring journal L'Europe Centrale. It was as a result of such initiative, despite his wealthy inheritance, that he had captured the hearts of the Genevese and became head of their government from 1848 to 1853 and again from 1855 to 1861 . Now he would foresake all that for the dubious honor of leading a fanatic and insensate minority.

Within an hour of the Coulouvrenière meeting its feelings were known throughout Geneva, including the foreign quarters, where the French, Italian, German, Russian, Belgian and Swiss (that is, those Swiss who accepted nominations) delegations decided that the next day they would propose that the Congress's final session be turned over entirely to Fazy and his dissident group. In this way the Congress might be saved, or at least, it would force the subversive group to come out into the open. Prior to this decision they had even considered the feasibility of transfering the Congress immediately to either Lausanne 
or Bern. Now they would turn over the final session to the Fazysts; and if the latter should succeed in their abortive attempt to render ineffective the resolutions of the Congress, by either preventing or by padding the vote with non-members, they unanimously agreed that as far as their delegations were concerned the resolutions were adopted and would constitute the basis for future action.

When the Congress's final session opened on Thursday September I 2 at nine o'clock in the morning, the session having been advanced to the morning in order to permit delegates to leave on the afternoon trains, the atmosphere was tense as both sides arrived determined for a showdown. The Fazysts, being the largest organized group, were particularly in evidence from eight o'clock on, with chefs de file giving instructions and others, hitherto unseen at the Congress, threateningly swinging clubs and gesticulating vociferously. By nine o'clock, as the doors of the Palais opened, this group was so large and unruly that it was no longer possible to examine identity cards; they stormed the entrance and the main section reserved for the members, so that they virtually surrounded the foreign delegations, especially the French, Italian and German. Two of these intruders, supposedly chefs de file until recognized as plainclothes policemen of some of Europe's despotic regimes, advanced right up to the tribunal stairs and posted themselves on each side for the remainder of the session. By opening time on the platform there were only a few individuals, some completely unknown and Fazy, who was ensconced in a committeeman's armchair even though he had no right to appear on the platform at all since he had refused to accept office. Not far off was Wessel, seated on the platform stairs. By nine fifteen the Directing Committee arrived, after having had a special session of its own, only to find insufficient seats for them. Some remained standing, others sat among the spectators. Close by were the journalists of the main newspapers of Europe, grouped around five tables, at one of which was the Congress's sole female correspondent, the daring Jesse White Mario, now reporting for English papers although well known in her own right as a veteran Garibaldian campaigner. Her husband, Alberto Mario, had likewise seen battle with Garibaldi, and here was acting as one of the secretaries of the Italian delegation. Apart from Mrs. Mario, some two hundred women attended in a section reserved especially for them. Everywhere one discussed the Coulouvrenière meeting the night before, and for the benefit of those who did not attend copies of the Journal de Genève, now violently anti-Congress, were distributed gratis. Its front-page editorial read:

"Les adhérents genevois du Congrès de la Paix s'opposeront 
énergiquement à toute résolution dangereuse pour la sécurité, et compromettante pour la neutralité de la Suisse, qui pourrait être proposée dans la séance d'aujourd'hui."

The psychological appeal now matched the emotional ones contrived by Bishop Mermillod and Fazy, so that the average Genevese's spirit could hardly have quickened more if the Savoyards were attempting another escalade of Geneva's Bastions.

Jolissaint opened the session frankly by acknowledging the seriousness of the situation, as demonstrated in the various opposing meetings held outside the Palais, and voiced his displeasure at seeing his fellow Genevese so intolerant to the ideas of others and the will of the Congress. He was very tired and his voice showed it; nevertheless he begged for calm and dignity, then announced that although forty-six speakers were scheduled before Fazy, Wessel and Carteret, the former were renouncing their turn in order that the latter might be heard again at this time, even though they had already spoken before. Fazy mounted the rostrum and in a lengthy and irrevelant speech, well over the fifteen minute limit, proposed that Questions I and 2 of the Manifesto be discarded as useless, while Question 3, on the setting up of the permanent organization, be postponed for three months. In fact, he concluded "je crois que ce qu'il y aurait de mieux à faire, ce serait d'ajourner ce Congrès... autrement les résolutions qui ont été présentées au Congrès risquent d'être rejetées." In other words, the very reason which distinguished this congress from all the previous ones on peace - the fonction politique or Questions I and 2, which made it possible to single out the threats to peace - were to be eliminated, and Question 3 reduced to impotency. This was, of course, tantamount to asking the Congress to commit its own suicide! Wessel, the political leader of Geneva's Independant Party, followed so closely that he demonstrated anything but independence, while Carteret raised the fear of a European carbonarism if the Congress's resolutions were allowed to become effective. When finally these three terminated their speeches, without any restrictions of time whatsoever, and the forty-six others who had renounced their turn in order to placate the Fazysts now permanently renounced their rights to speak, so that the session might progress, cloture of general discussion was moved and passed. Here it was already the last day and nothing but general speeches had taken place! Even then, it seemed almost destined not to be, as three scheduled speakers insisted upon being heard. But the audience was utterly worn out with speeches by this time and refused to listen when these last attempted to adress them.

Barni, substituting for Jolissaint, who was no longer physically able 
to conduct the session, now called for a vote on the Fazy proposals by a show of hands. Decisively they were voted down, despite the illegal voting by persons not members who had forced their way into the restricted area, some of whom even voted with both hands! ${ }^{1} \mathrm{~A}$ roar of protest met the announcement: "Nous sommes les plus nombreux! Nous nous sommes comptés d'avance! Nous sommes chez nous!Nous ne voulons pas qu'on nous fasse la loi! A bas! A bas!" Notwithstanding, the vote was correct, for it had been first made by counting those in favor of Fazy's proposals, then by counting those opposed, the result being a definite majority against the proposals.

But the protest soon grew to a tumult, with the intruders beating down upon the journalists' desks with their clubs, pounding the floor with their feet, and rending the air with their vociferations. The Directing Committee went into a huddle and after a few moments decided to propose another vote, so sure were they of success. This time voting was by rising in one's place, and again, even more emphatically than before, the Fazy proposals were defeated! ${ }^{2}$ Bedlam broke loose; whistles shrieked from one end of the Palais to the other; threats were hurled freely about, especially by a gang of hoodlums who broke into the inner circle and crowded the platform stairs. At the right of the platform another riotous group was seen imploring their chef for a go-ahead signal. And as the deplorable scene showed no sign of relenting Jolissaint drew up to Fazy and begged: "Au nom de l'honneur suisse, je vous adjure d'imposer la décence aux vôtres... Si l'ordre est troublé, je vous en rends responsable." But Fazy's sole answer, which he denied later, was: "Je n'y puis rien."

Secretary of the French delegation, Chassin, now begged Wessel in a similar manner, whereupon the latter mounted the rostrum and within seconds brought the disgraceful scene to an end by simply saying:

"Voudriez-vous faire de ce Congrès une affaire tout à fait genevoise? Cela ne saurait être. Laissez à cette assemblée la facilité d'accomplir son œuvre préparatoire et poser les bases d'une œuvre humanitaire... j'ai voté pour la proposition Fazy, le bureau nous dit qu'elle a réuni contre elle la majorité, il faut le croire." Apparently Wessel also realized

1 Lemonnier, p. 27; Annales, 299.

2 Typical of the clerical opinion on the voting was minister David Munier's Le Congrès international de la Paix à Genève (Extrait des Étrennes Religieuses pour 1868), Genève, Imp. Soullier, Landskron et Wirth, I 868, who on p. 37 says: „Je n'aurais pas hésité à décider, en conscience, que la proposition était adoptée. M. Barni, en jugea autrement, et la déclara de nouveau rejetée." For a contrary opinion, however, see Réponse de $\mathbf{M}$. Barni à M. le pasteur Munier, Annales, Doc. 5, pp. 379-381, for a conclusive refutation of Munier's accusations. 
that Genevese honor was at stake, even though his reference to the Committee's count did not in fact condemn the demonstrators. A propos, Barni interjected: "Nous ferons encore une épreuve, si vous voulez." But Wessel knew that it would have been useless because the open voting was readily checked by all present; he declined the new offer and the Fazy proposals became nullities. Now arrived the time to vote upon the all-important resolutions derived from the manifesto's three questions, and as the reader in rereading them came to the part "... décide, en outre, qu'il sera constitué un Comité central permanent..." shouts once more rent the air, this time with: "Pas à Genève! Pas à Genève!" But the die had already been cast and the resolutions were adopted by the greatest majority seen that day. ${ }^{1} \mathrm{~A}$ final outburst rang out from the dissident Genevese, who dared hurdle the guard rail protecting the delegations and climb upon the platform, challenging officials and members everywhere. But calmly Jolissaint, back on the rostrum after a brief rest, asked for silence and when the demonstrators refused, he charged the Directing Committee with final instructions for selecting the next congress date. A moment later he announced the agenda exhausted and the meeting adjourned. ${ }^{2}$ Proudly, amid the harassment, the delegates withdrew from the Palais Electoral and its vociferous and gesticulating hosts; they had created the first permanent international peace organisation, which one day was to lead to the League of Nations, and ultimately, the United Nations.

The next day the press commented upon the Congress in a manner just about as expected after its latest reactions. "...les adhérents genevois du Congrès ont vainement manifesté deux fois", wrote the Journal de Geneve referring to the voting, "leur intention d'en finir avec ces éternels lieux-communs dont on nous rebat les oreilles depuis trois jours." In regards to President Jolissaint's offer to the Genevese public raised at one point during Thursday's climactic session, to transfer the Congress to Bern, the same journal also remarked sourly: "Nous ignorons si $\mathrm{M}$. Jolissaint a été autorisé par ses collègues à faire une semblable invitation, mais si cette promesse se réalise, nous n'envierons pas à nos compatriotes bernois le plaisir d'assister pendant trois jours à d'aussi inutiles déclamations." Other papers of Geneva were less

${ }^{1}$ Still it is surprising to read in Fazy's Mémoires, op. cit., p. $21_{4}:$ „... il y eut évidemment un vote contraire; néanmoins, le président déclara l'article adopté." For a similar opinion, L'Illustration, Paris, op. cit., p. I82. Munier, op. cit., p. 37, disclaims that a vote was taken at all - Jolissaint walked out and never returned - (and) „le Congrès s'est dissous dans la confusion, avant d'avoir transmis à personne l'hétitage de ses pouvoiis et l'exécution d'aucune mesure!"

2 Fazy, Mémoires,p. 2 I s, apparently agreed with Munier, for he speaks of the "dissolution" of the Congress and blames the "excentricités de suspects éminents" for it. 
vicious, if similarly reactionary. The Messager de Genève was characteristic, for on September I already it had expressed little faith in the Congress's outcome by quoting Leibnitz as saying, "la paix perpétuelle, pax perpetua, n'est possible qu'au cimetière, car les morts ne se battent pas entre eux." Now that it was all over, on September is, it blamed the Directing Committee for "tout Genève proteste contre l'usage qui a été fait de la liberté de la tribune dans le Congrès." Roehrich's Discours en vers aux membres du Congrès de la Paix, ${ }^{1}$ which was written right after the Congress and appealed to love of the Bible and Christ as the only road to peace, represented, more or less, this group's feelings. La Démocratie Suisse was more realistic: first it showed that Garibaldi brought with him a principle - "que le vrai, le seul souverain est le peuple, (et) que le peuple peut déléguer cette souveraineté, mais qu'il ne doit ni l'aliéner et ni se la laisser confisquer." Fazy's attitude it could not understand, however. How could he first praise Garibaldi, then act shocked when the latter expressed himself in Geneva, for the whole world knew what the Italian revolutionary's ideas were for twenty years already. "C'était vraiment curieux", it wrote. ${ }^{2}$ This was getting to the crux of the matter. In fact it reminded one of Fazy's welcome, as head of the Genevese government, to the fleeing Mazzini in 1849 , after the collapse of the Roman Republic, only to turn against the ex-Roman triumvir later. ${ }^{3}$

At the same time the Journal de Genève looked rather ludicrous as it published its correspondent's dispatch from Birmingham, England, where the Workers' Peace Meeting was "pledging itself to propagate in that country the ideas encompassed in the Geneva Congress. It may be only a weak beginning", the dispatch concluded, "but great things might come of it". ${ }^{4}$ Simultaneously the London's International Workingmen's Association was inviting Garibaldi to represent Italian labor in its forthcoming celebration of labor's victory in Parliament at Crystal Palace, while London's League for Electoral Reform was similarly hoping that he would accept its invitation to its annual banquet towards the end of September. The same approving attitude came from the Journal's Paris correspondent: "Le Congrès de Genève absorbe l'attention publique. La réception que vos compatriotes ont faite à Garibaldi a fait venir l'eau à la bouche des Parisiens si désireux depuis longtemps de voir le célèbre agitateur italien, de se porter à sa rencontre et de le fêter par une bienvenue splendide. 'Ah!' dit-on, 'si

\footnotetext{
${ }^{1} \mathrm{~L}$ (ouis) R(oehrich), Discours en vers... Imp. Bonnant, 1868, Genève.

${ }^{2}$ La Démocratie Suisse, Genève, 13 Septembıe, 1867 ; see also Samedi 7 Septembre.

${ }^{3}$ Mazzini's Letters to an English Family, I844-1854, edited and with an intro. by E. F. Richards, London \& New Yotk, John Lane, 1920, p. $13 \mathrm{I}$.

4 Journal de Genève, I2 Septembre 1867.
} 
Garibaldi venait ici, quel enthousiasme! quels applaudissements! quels vivats! Vous avez pu faire ce qui nous est interdit." '1 And concerning the Congress's disorder L'Avenir National, of Paris, succintly placed all the blame upon Fazy, whom it called the "ex-dictateur de Genève" who personally wanted the Congress's presidency, and when that was not to be joined forces with the reaction. ${ }^{2}$ It was calling a spade a spade. The Courrier Français summarized it all as an indictment against Fazy, as follows: ${ }^{3}$ "On sait qu'il existe à Genève deux groupes politiques principaux, les conservateurs et les radicaux... Le radicalisme genevois est personnifié depuis plusieurs années en M. James Fazy; mais grâce à ce profond politique, la désorganisation du parti est aujourd'hui presque complète." Back in Geneva an open letter signed by Charles Fauconnet D.M., the head of the Masonic lodges of Geneva, and by 504 fellow members was published in the newspapers, including the Journal, "pour affirmer une fois de plus le but qu'ils se sont toujours proposés, c'est-a-dire l'établissement de la paíx universelle: en conséquence, ils s'unissent aux efforts tentés par le Congrès". 4 The most effective critique, however, was that of Le Carillon de Saint Gervais, the Socialist newspaper which represented the majority of Geneva's watch industry workers of the quartier Saint Gervais, the humble section made famous by its great native Jean Jacques Rousseau and by its sponsoring of Karl Marx's First International only the year before. Being more conscious of the horrors of war because of the perennial exploitation of its ranks by despots, the paper endorsed the Congress as "une puissante manifestation des aspirations de tous les peuples" as opposed to "une fraction fanatique, dont l'intolérance rivalise avec l'intolérance de nos vieux calvinistes autoritaires". And in regards to Garibaldi, whom the reactionary press was lambasting mercilessly in contrast to its acclaim scarcely one week before, the Carillon concluded: "Pourquoi ces calomnies indignes contre un homme que tous les gens impartiaux admirent?... Non, vous ne découragerez pas ce grand cœur... Le pouvoir temporel, le seul attaqué par Garibaldi, doit en effet disparaître pour la paix du monde entier, comme pour la paix du peuple italien, qui ne pourra affirmer ses libertés et ses aspirations que quand il aura repoussé de son sein un pouvoir dont les prétentions politiques, doublées de ses aspirations à l'universelle domination, sont une menace constante à l'harmonie de la société... Ce sera l'honneur éternel de Garibaldi d'avoir affranchi l'Europe du joug écrasant d'un

1 Ibid., I 3 Septembre.

2 Also reprinted in: La Suisse Radicale, jeudi is Septembre 1867.

3 Vendredi ${ }_{3} 3$ Septembre ${ }^{3} 867$ and in: La Suisse Radicale of same date.

4 Journal de Genève, vendredi 13 Septembre 1867. 
pouvoir aveuglé par quinze siècles de prépondérance et d'iniquités impunies". 1

Instead the Journal de Genève's attack on Garibaldi knew no limit and was the worst that any newspaper dared print. Hypocritically and shamelessly it belittled the maker of united Italy by saying that "la conquête de Naples est considérée comme un précédent, mais ce n'est pas Garibaldi qui a pris Naples : c'est Cialdini [for Victor Emmanuel] sur le Volturno et à Gaëte. Garibaldi, c'est la légende, mais l'histoire, c'est Victor Emmanuel". ${ }^{2}$ Then for a fortnight the Journal continued its attacks daily, until October 2, when it commented upon Garibaldi's arrest by Premier Rattazzi: Why had the Congress been called a peace congress? Why had Garibaldi been invited? "...Le premier succès qu'ils peuvent enregistrer, c'est l'emprisonnement de Garibaldi!" On the same day Pius IX was affixing his papal bull with apostolic benediction upon a congratulatory letter being sent to Notre vénérable Frère Gaspard, Évêque d' Hébron, Auxiliaire de Genève for the part he had played in "ce triomphe de la bonne cause" at the Congress and thus having frustrated "la ruine de la puissance ecclésiastique et du pouvoir civil". ${ }^{3}$ In the same vein was the Gazette de Chambery, of the ultraCatholic Savoyard capital ninety kilometres from Geneva, which called Garibaldi a dunce and thanked the Conseil Fédéral for having ordered "un Jeûne d'actions de grâces, pour remercier Dieu de l'avoir éloigné de la Confédération"," which, of course, was untrue. The Gazette du Valais wrote likewise in leading its Catholic canton's sentiment against Garibaldi with the grossest invectives. ${ }^{5}$

But the final word rested with Garibaldi, who in the meantime reached Genestrello, near Voghera, Italy, en route to practice what he preached, namely to destroy "cette pestilentielle institution que l'on appelle la papauté". He would despoil Pius IX of his temporal power, even if he had to attack the meddling troops of Napoleon III to do it, those same troops which he once defeated on April 30,1849 but which soon after returned, stealthily, to reestablish pontifical Rome and the prestige

\footnotetext{
${ }^{1}$ Le Carillon de Saint Gervais, Genève, samedi 14 Septembre 1867.

${ }^{2}$ Vendredi I 3 Septembre 1867.

${ }^{3}$ Letter published in: Annales, pp. $37^{8-379}$.

4 Reprinted from: Le Carillon de Saint Gervais, 21 Septembre 1867.

${ }^{5}$ For lengthier attacks from the Catholic side, see: Avant, pendant et après, ou Garibaldi à Genève, Imp. Catholique J. Duraford, $1867,16^{\circ}, 55 \mathrm{p}$. Numerous unfounded charges, some involving the Genevese police for "conspiring" with Garibaldi, are herein presented. Also, L. Mr. S.-A., Les quatres journées du Congrès de la Paix à Genève, Genève, $\mathrm{J}$. Duraford, $1867,8^{\circ}, 76 \mathrm{p}$. Garibaldi is compared to Luther, Voltaire and Calvin by the author, who is a priest and thanks the Genevese Catholics for their actions in behalf of the clergy.
} 
of Napoleon as well. Now, he who epitomized the Congress's will to eliminate Europe's remaining despots, read of the adverse propaganda being circulated by Geneva's reactionaries and sent back this refutation to those who would defame him and the Congress: ${ }^{1}$

"Chers amis,

'Garibaldi s'est enfui de Genève. Le Congrès de la Paix a été dissous par les radicaux.

Fiasco complet de la démocratie universelle. ${ }^{1}$

Voilà ce qu'ont crié aux quatre vents les espions, les agents provocateurs et les mouchards confondus ensemble sur le sol libre de la belle reine des lacs.

Et les organes des patrons des mouchards, et les espions qui puisent comme eux dans les dépenses secrètes, leur ont fait écho, luttant de sollicitude, d'empressement pour annoncer l'agréable nouvelle aux puissants de la terre.

Cependant, je ne me suis pas enfui de Genève, je ne me suis pas échappé incognito et sans être salué, comme veulent le dire les journaux de la réaction et de l'obscurantisme. J'ai prévenu tous mes amis le jour de mon arrivée à Genève, que j'en partirais le i I, et mes amis sont venus me saluer à mon départ.

Quant au Congrès de la Paix, il y a eu quelque altercation, je dois l'avouer.

Mais cela n'enlève rien de la valeur des vérités que les hommes libres de ce Congrès ont proclamées. Que l'on pense au grand nombre d'agents de la police européenne qui se sont trouvés apostés dans le Congrès, ayant pour mot d'ordre de le troubler et de l'annihiler, s'il était possible.

Et malgré tout cela, le Congrès de la Paix n'a pas fait fiasco. Les nobles initiateurs de cette très-noble pensée peuvent se réjouir, dans leur conscience honnête, d'avoir fait un grand bien à l'humanité.

Oui, sous les auspices d'une généreuse population de l'Helvétie, non loin du site sacré du Grütli, où commença la fraternité des peuples, où il fut prouvé au monde que les montagnes, les fleuves, la langue, ne divisent pas la famille humaine, mais que ce qui la divise, ce sont les prêtres et le despotisme.

Oui, sous vos auspices, fils de la Rome de l'intelligence, les représentants de la partie progressive des peuples se sont serré la main et ont jeté les fondements du culte de la justice et de la vérité qui doivent à la fin prévaloir sur la terre, quand les nations com-

1 Annales, pp. 376-377; Lemonnier, pp. 46-47; for the Italian version, Edizione Nazionale degli scritti di Giuseppe Gatibaldi, Bologna, L. Cappelli, 1932-37, V, Pp. 41 2-4I3; as well as in many European newspapers of the times. 
prendront que leur argent doit être employé à des œuvres utiles et non à l'achat de cuirasses, de bombes, de mercenaires et d'espions.

Genestrelle, 16 Septembre.

G. Garibaldi”.

And even the Journal de Genève, which was mainly responsible for having abetted the Genevese reactionaries, admitted the truth of this letter by severely criticising the protesting local press and church groups, which now went so far as to announce that Garibaldi had been asked by the Conseil d'État to leave Geneva prematurely. ${ }^{1}$ The abettor was evidently frightened by the very monster it had created.

$$
* * *
$$

As a matter of record the idea of the Congress lived on, despite those who believed it could not survive, for the next forty-seven years, until I 9I4, in fact, when the first great world war disrupted its activities for four years, then at its conclusion brought in its place, and those of the numerous other peace organizations which had in the meantime appeared, the League of Nations in Geneva. On October 10, 1867 the Permanent Central Committee was formed in Bern, and on 20-21 of that month the League for Peace and Liberty held its first séances, while in November specimen issues of Les Etats-Unis d'Europe, the League's official newspaper, appeared. Beginning January I, I868 it began regular weekly publication in two editions, one in French, and the other in German, which also lasted until 1914. Congresses were held in various cities - Lausanne, Bern, Lugano, etc. - but from the sixth congress, held in Geneva again in 1872 , the remainder were all in that city. Among its many noteworthy publications were Louis Simon's Question de l'Alsace et de la Lorraine, Charles Lemonnier's Nécessité d'une Juridiction Internationale, Emile Arnaud's Code International Public, and others.

${ }^{1}$ Editorial p. I, jeudi 26 and vendredi 27 Septembre 1867; and p. 3, rer Octobre 1867. 